\author{
Assistant Professor Jelena ANDRAŠIĆ, PhD \\ E-mail: jelenadj@ef.uns.ac.rs \\ Faculty of Economics in Subotica, University of Novi Sad, Serbia \\ Teaching Assistant Branimir KALAŠ, MsC \\ E-mail: branimir.kalas@ef.uns.ac.rs \\ Assistant Professor Vera MIROVIĆ, PhD \\ E-mail: vera.mirovic@ef.uns.ac.rs \\ Assistant Professor Nada MILENKOVIĆ, PhD \\ E-mail: nadam@ef.uns.ac.rs \\ Assistant Professor Miloš PJANIĆ, PhD \\ E-mail: milospjanic@ef.uns.ac.rs \\ Faculty of Economics in Subotica, University of Novi Sad, Serbia
}

\title{
ECONOMETRIC MODELLING OF TAX IMPACT ON ECONOMIC GROWTH: PANEL EVIDENCE FROM OECD COUNTRIES
}

\begin{abstract}
The research paper provides an empirical evaluation of the tax effects on economic growth in 35 OECD countries from 1996 to 2016. The objective of this paper is to find how taxes effect on the economy, where analysis involves gross domestic product as a proxy for economic growth. Ensuring fundamental econometric procedures, the research paper reflects fixed effect model which measure the impact of tax revenue growth, personal income tax, corporate income tax, social security contributions, tax on goods and services and tax on property on dependent variable as a gross domestic product. The analysis includes main macroeconomic determinants as an inflation, unemployment, government expenditure and investment in observed countries. Results show that $1 \%$ increase of tax revenue growth enhances the gross domestic product for $0.29 \%$ which is confirmed previous studies that manifested significant and positive relationship between these variables. Further, there is recorded the significant and positive effect of tax on property on economic growth, where $1 \%$ increase of this tax form raises a gross domestic product for $0.21 \%$. On the contrary, tax on goods and services have a harmful effect on economic growth, where $1 \%$ increase of them cause gross domestic product drop of $0.60 \%$, which is statistically significant.
\end{abstract}

Keywords: taxes, economic growth, modelling, panel fixed effect, OECD.

JEL Classification: C23, C51, H2, O11, O23

\section{Introduction}

The economic essence of a state is reflected in taxes and they manifest economic expression of the state existence. In this way, they are determined as the price that must be paid for state services. The modern approach to public finance emphasises 
Jelena Andrašić, Branimir Kalaš, Vera Mirović, Nada Milenković, Miloš Pjanić

that taxes give a contribution to economic efficiency and fair income distribution. So, when we analyse taxes it is essential to determine their optimal level in the economy. Mankiw et al. (2009) define optimal tax theory in a way that only an adequately created tax system can lead to the maximization of the social wealth function. Taxes are important and their fundamental purpose is reflected in the collection of funds to finance public spending and cover public needs. Taxes and their impact on economic growth usually question in public finance where many papers have researched the effects of taxes on economic performance such as Mendoza et al. (1997); Daveri and Tabellini (2000) and Arnold et al. (2011), with no consensus on the impact and significance of taxes on economic growth (Alinaghi, 2015). However, it is important to emphasise that tax structure and level can have an essential impact on the economy. When it comes to economic growth, Solow (1956) defined neoclassical growth model where taxes and spendings have on impact on economic growth on long-run and this model favours the rate of technical progress and population growth. Subsequently, Barro (1990) points out the role of taxes and their effect on economic growth, so he explained the endogenous growth model by considering the accumulation of physical and human capital. The structure of this research is as follows. After the introduction, there is a literature review where similar research analysis is presented. The third section is methodology which defines variables and all econometric procedure as well as preconditions for proper panel regression model. The fourth section is an analysis of macroeconomic determinants and taxes in OECD countries from 1996 to 2016. The next section is empirical results of determined fixed effect model, where are selected which taxes are significant for economic growth. The last section summarizes the findings and conclusions with recommendations for future research.

\section{Literature review}

There are many studies that have examined the impact of taxes on economic growth (Barro, 1990; Myles, 2000; Lee, Gordon, 2005; Tosun, Abizadeh, 2005; Pjesky, 2006; Bania et al. 2007; Arnold, 2008; Reed, 2008; Romer, Romer, 2010; Barro, Redlick, 2011; Gemmell et al. 2011; Ferede, Dahlby, 2012; Mertens, Ravn, 2013; Li, Lin, 2015; Gale et al. 2015). When we mention economic growth, it is essential to define this category and Myles (2000) determines economic growth as the basis for increasing prosperity, where gross domestic product is usually proxy for the growth of a country. Lee and Gordon (2005) analyzed seventy countries over the period 1980-1997 and found corporate income tax is related to lower economic growth. Their findings showed that a cut in the statutory corporate rate of $10 \%$ increases annual gross domestic product growth per capita by about $0.7 \%$ to $1.1 \%$. Arnold (2008) examined the relationship between taxes and economic growth for 21 OECD countries and found that income taxes are generally associated with lower economic growth than taxes on consumption and property. In empirical research of 17 OECD countries for the period 1970-2004, Gemmell et 
Econometric Modelling of Tax Impact on Economic Growth: Panel Evidence from OECD Countries

al. (2011) concluded that direct taxes are more harmful to economic growth with special emphasis on personal income tax and corporate income tax. Similarly, Barro and Redlick (2011) investigate how the decline of marginal tax rate effect on gross domestic product per capita in the United States from 1912 to 2016. Results found that cut in the average marginal tax rate of $1 \%$ increases gross domestic product per capita by around $0.5 \%$ in next year. Further, Mertens and Ravn (2013) showed that $1 \%$ cut in the average personal income tax rate increases real gross domestic product per capita by $1.4 \%$ in the first quarter and by up to $1.8 \%$ after three-quarter. Likewise, the same decline of average corporate income tax rate up real gross domestic product per capita by $0.4 \%$ in the first quarter and by $0.6 \%$ after one year. In their research, Li and Lin (2015) analysed the effect of sales tax on economic growth in the United States from 1960-2013 and estimated the longrun and short-run elastic coefficients of sales tax on growth. Their study found that economic growth responds negatively to sales tax in the long-run, although this tax form has positive effects in the short-run.

\section{Methodological framework}

\section{1. Data description}

This segment provides annual observations for thirty-five OECD countries (Table 1) for the period 1996 to 2016, where data are used from Revenue Statistics OECD and World Economic Outlook Database - International Monetary Funds.

Table 1. Review of explanatory countries

\begin{tabular}{l|l|l|l|l|l|l}
\hline Australia & Austria & Belgium & Canada & Chile & $\begin{array}{l}\text { Czech } \\
\text { Republic }\end{array}$ & Denmark \\
\hline Estonia & Finland & France & Germany & Greece & Hungary & Iceland \\
\hline Ireland & Israel & Italy & Japan & Korea & Latvia & Luxembourg \\
\hline Mexico & Netherlands & $\begin{array}{l}\text { New } \\
\text { Zealand }\end{array}$ & Norway & Poland & Portugal & Slovakia \\
\hline Slovenia & Spain & Sweden & Switzerland & Turkey & $\begin{array}{l}\text { United } \\
\text { Kingdom }\end{array}$ & $\begin{array}{l}\text { United } \\
\text { States }\end{array}$ \\
\hline
\end{tabular}

Source: Authors illustration

The aim of the study is to reflect which determinants are essential for economic growth with special emphasis on tax forms as a tax revenue growth, personal income tax, corporate income tax, social security contributions, tax on goods and services and tax on property. Also, the analysis included inflation, unemployment, government expenditure and investment as one of the main indicators in the economy. 
Jelena Andrašić, Branimir Kalaš, Vera Mirović, Nada Milenković, Miloš Pjanić

Table 2. Review of explanatory variables

\begin{tabular}{l|c|c|l}
\hline Variable & Notation & Calculation & Source \\
\hline Gross domestic product & GDP & Annual rate & $\begin{array}{l}\text { International } \\
\text { Monetary Fund }\end{array}$ \\
\hline Inflation & INF & Annual rate & $\begin{array}{l}\text { International } \\
\text { Monetary Fund }\end{array}$ \\
\hline Unemployment & UNM & Annual rate & $\begin{array}{l}\text { International } \\
\text { Monetary Fund }\end{array}$ \\
\hline Government expenditure & GE & $\%$ of GDP & $\begin{array}{l}\text { International } \\
\text { Monetary Fund }\end{array}$ \\
\hline $\begin{array}{l}\text { Investment } \\
\text { Tax revenue growth }\end{array}$ & TRgrowth & Annual rate & $\begin{array}{l}\text { International } \\
\text { ONCDetary Fund }\end{array}$ \\
\hline Personal income tax & PIT & $\%$ of GDP & OECD \\
\hline Corporate income tax & CIT & $\%$ of GDP & OECD \\
\hline $\begin{array}{l}\text { Social security } \\
\text { contributions }\end{array}$ & SOC & $\%$ of GDP & OECD \\
\hline $\begin{array}{l}\text { Tax on goods and } \\
\text { services }\end{array}$ & TOG & $\%$ of GDP & OECD \\
\hline Tax on property & TOP & $\%$ of GDP & OECD \\
\hline
\end{tabular}

Model estimation is presented as:

$G D P_{i t}=\alpha_{0}+\beta_{1} I N F_{t}+\beta_{2} U N M_{t}+\beta_{3} G E_{t}+\beta_{4} I N V_{t}+\beta_{5}$ TRgrowth $_{t}+\beta_{6} P I T_{t}+\beta_{7} C_{\text {CIT }}+$ $\beta_{8} S O C_{t}+\beta_{9} T_{O G G_{t}}+\beta_{10} \mathrm{TOP}_{t} \mu_{i t}$

where explanatory variables are determined as:

- Gross domestic product - market value of final goods and services produced within a country in a year, measured by annual growth rate;

- Inflation - general price level rise, measured by annual growth rate;

- Unemployment - a situation where someone of working age is not able to get a job, measured by annual growth rate;

- Government expenditure - consists of total expense and the net acquisition of non-financial assets, measured by percentage share of gross domestic product;

- Investment - the total value of the gross fixed capital formation and changes in inventories and acquisitions fewer disposals of valuables for a unit or sector, measured by percentage share of gross domestic product;

- Tax revenue growth - tax revenue collected from taxes on income and profits, social security contributions, taxes levied on goods and services, ownership and transfer of property;

- Personal income tax - tax levied on the net income and capital gains of individuals, measured by percentage share of gross domestic product; 
Econometric Modelling of Tax Impact on Economic Growth: Panel Evidence from OECD Countries

- Corporate income tax - tax levied on the net profit and capital gains of enterprises, measured by percentage share of gross domestic product;

- Social security contributions - compulsory payment paid to government that confers entitlement to receive a future social benefit, measured by percentage share of gross domestic product;

- Tax on goods and services - tax levied on the production, extraction, sale, transfer leasing or delivery of goods, measured by percentage share of gross domestic product;

- Tax on property - recurrent and non-recurrent tax on the use, ownership or transfer of property, measured by percentage share of gross domestic product.

\subsection{Panel model specification}

In econometric research, the use of panel data has wide implementation because it enables integration of spatial and temporal dimensions. Namely, panel data includes a large number of the same observation units at different times. Econometric analysis of time series is based on the assumption that available data fulfil stationary as one of the most important preconditions in the econometric procedure. It means constantly of means and variance of the time series. The presence of stationary is one of the conditions for the adequate statistical conclusion in time series analysis and it will be used LLC test, IPS test, Fischer test, Breitung test and Harris-Tzavalis test. These tests include the null hypothesis:

$\mathrm{H}_{0}$ : Panels contain unit roots.

If p-values of used tests are less than 0.05 we can reject the null hypothesis and conclude panels are stationary and accept the alternative hypothesis:

Ha: Panels are stationary.

Likewise, the absence of multicollinearity is important assumptions in the regression model, which implies there is no high correlation between independent variables in the defined model and it will be used VIF test (Asteriou and Stephen, 2007):

$Y=\beta_{1}+\beta_{2} X_{2}+\beta_{3} X_{3}+\mu$

where hypothetical values for $\mathrm{X}_{2}$ and $\mathrm{X}_{3}$ are below:

$X_{2}^{\prime}=12345$ 
Jelena Andrašić, Branimir Kalaš, Vera Mirović, Nada Milenković, Miloš Pjanić

$X_{3}^{\prime}=246810$

The Hausman test is one of an essential test in the panel model data which enables correct selection between fixed effect model and random effect model. The null hypothesis is there is no large difference in the estimated values of fixed effect model and random effect model. Based on acceptance or rejection of the null hypothesis, this test shows which model is necessary to apply in econometric analysis. In the case of rejection of the null hypothesis, fixed effect model is an adequate model or random effect model is not appropriate.

$H=\left(\beta^{F E}-\beta^{R E}\right)^{\prime}\left[\operatorname{Var}\left(\beta^{F E}\right)-\operatorname{Var}\left(\beta^{R E}\right)\right]^{-1}\left(\beta^{F E}-\beta^{R E}\right) \approx \chi^{2}(k)$

Fixed effect model includes the assumption that a constant changes with each observation unit, where it is constant in time and it can be defined as:

$Y_{i t}=\alpha i+\beta_{1} X_{i t l}+\beta_{2} X_{i t 2}+\ldots \beta_{n} X_{i t n}+\mu_{i t} ; i=1, \ldots, N ; t=1, \ldots, T$

where $\mathrm{N}$ denotes number of observations, $\mathrm{T}$ number of period, $\alpha$ constant, $\beta$ parameters, $\mu$ random error. Stochastic effect model implies random selection of observation units and assume the difference between them are random. It can be determined as:

$Y_{i t}=\beta_{1 i}+\beta_{2} X_{i t 2}+\ldots \beta_{n} X_{i t n}+\mu_{i t}$

$\beta_{1 i}=\beta_{1+} \varepsilon_{i} \quad i=1,2, \ldots, N$

$Y_{i t}=\beta_{1}+\beta_{2} X_{i t 2}+\ldots \beta_{n} X_{i t n}+\varepsilon_{i}+\mu_{i t}$

$\beta_{1 \mathrm{i}}$ stochastic variable with mean value $\beta_{1}$, while $\varepsilon_{\mathrm{i}}$ represents a random error with mean value 0 и variance $\sigma^{2} \varepsilon$.

\section{Macroeconomic framework and taxes in OECD countries}

Before we see how taxes effect on economic growth in OECD, it is important to analyze their trends and level for the observed period. First, it is presented the trend of macroeconomic determinants as gross domestic product, inflation, unemployment, government expenditure and investment. 
Econometric Modelling of Tax Impact on Economic Growth: Panel Evidence from OECD Countries

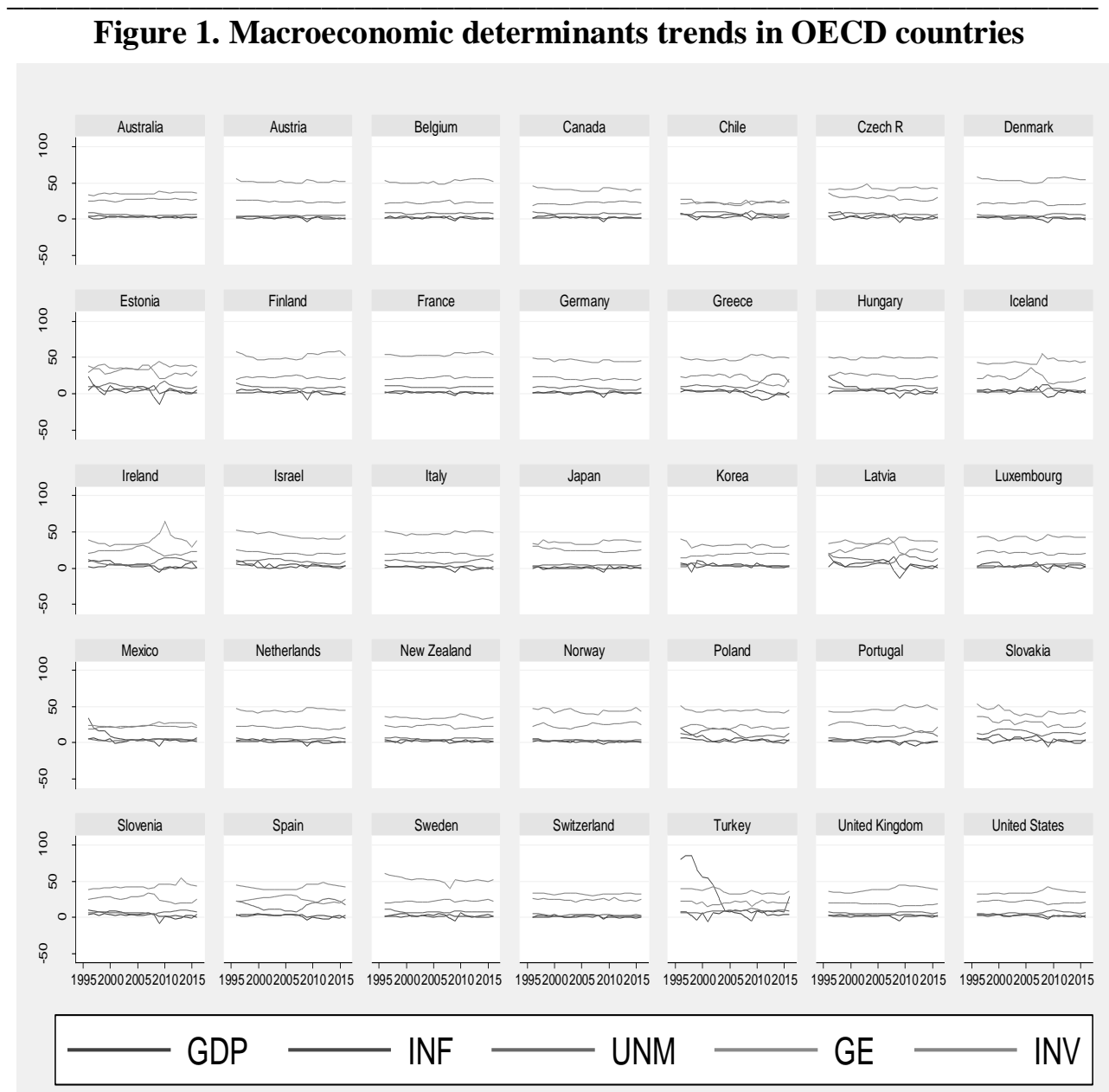

Figure 1 shows the trends of gross domestic product, inflation, unemployment, government expenditure and investment in OECD from 1996 to 2016. Looking at countries, the highest average GDP growth rate was recorded in Estonia, Ireland, Latvia and Turkey where it was above $4 \%$. On the other hand, countries as Greece, Italy and Japan had slower growth and recorded average rates below $1 \%$. Particularly refers to Greece that recorded an average GDP decline of $4.95 \%$ in the period 2008-2013. Interestingly, in the most developed countries such as Germany, United States or the United Kingdom, GDP growth was below the OECD average at $2.59 \%$. Also, countries which achieved the highest economic growth rate such as Estonia and Latvia had the highest average inflation in the observed period and it was at the level of $4.6-5 \%$. However, Turkey is ranked as the country with the 
Jelena Andrašić, Branimir Kalaš, Vera Mirović, Nada Milenković, Miloš Pjanić

highest average inflation of $28.79 \%$ as a result of the inflationary crisis in the period 1996-1999 when the average inflation rate was $78.87 \%$. The average unemployment rate in OECD countries is $7.72 \%$, the highest in Greece and Spain where it exceeds $15 \%$, while Switzerland has the smallest unemployment rate of $3.23 \%$ in the observed group. Finally, it should be noted that the average share of government expenditure is $41.62 \%$ and investment $23.45 \%$ of gross domestic product in OECD countries. When it comes to government expenditure, the highest percentage share about 50\% is recorded in Austria, Belgium, Denmark, Finland, France and Swede, while for example in countries such as Chile and Korea it is at the level of $20 \%$ or below. On the other hand, Korea has the highest percentage share of investment at $31.88 \%$ which is $10 \%$ more than the United Kingdom or the United States in the observed period.

Figure 2. Taxes trends in OECD countries

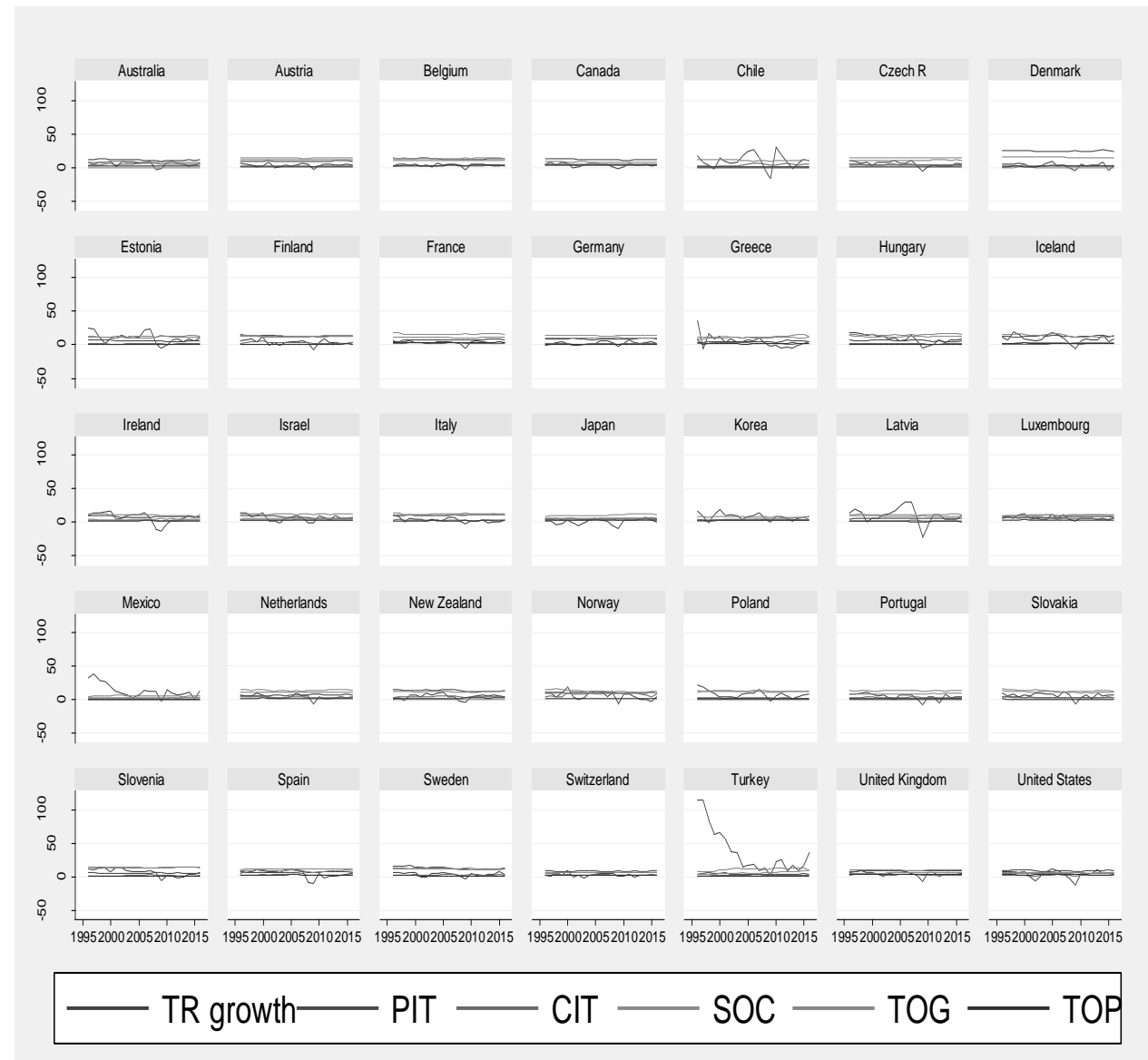


Econometric Modelling of Tax Impact on Economic Growth: Panel Evidence from OECD Countries

After that, we represent taxes trends in OECD countries, where the study includes the main tax forms as tax revenue growth, personal income tax, corporate income tax, social security contributions, tax on goods and services and tax on property. Based on Figure 2, average tax revenue growth is $6.63 \%$, where personal income tax, social security contributions and tax on goods and services make for almost a third of tax revenue. Tax on goods and services has the highest share $10.77 \%$ of GDP, social security contributions with $8.75 \%$ and personal income tax share $7.76 \%$ of GDP. Likewise, the average share of corporate income tax is $2.99 \%$ while tax on property share of GDP is $1.78 \%$. Looking at countries, Denmark and Norway have the highest share of personal income tax of $24.5 \%$ and corporate income tax of $8.4 \%$ of the gross domestic product. Austria, Belgium and Hungary have the highest social security contributions share of GDP, respectively at $15.4 \%$, $14.3 \%, 13.8 \%$ and $12.3 \%$. Similarly, the average percentage share of tax on goods and services is the highest in Denmark and Hungary where it is at level $15.4 \%$. When it comes tax on property share of GDP, it is the highest in United Kingdom $3.8 \%$ and Canada $3.6 \%$, France $3.1 \%$, while this tax form is minor in countries such as Austria, Czech Republic, Estonia, Germany, Hungary, Mexico Slovakia and Turkey where average percentage share is at level from $0.5 \%$ to $0.9 \%$

Table 3. Comparative review of TAX/GDP in OECD countries

\begin{tabular}{l|c|c|c|c|c|c|c}
\hline Country & AUS & AUT & BEL & CAN & CHI & CZE & DEN \\
\hline TAX/GDP & $28.5 \%$ & $42.0 \%$ & $43.5 \%$ & $32.8 \%$ & $19.9 \%$ & $33.4 \%$ & $46.3 \%$ \\
\hline $\begin{array}{l}\text { Gap to } \\
\text { OECD }\end{array}$ & $-5 \%$ & $8.5 \%$ & $10.0 \%$ & $-0.7 \%$ & $-13.6 \%$ & $-0.1 \%$ & $12.8 \%$ \\
\hline Country & EST & FIN & FRA & GER & GRE & HUN & ICL \\
\hline TAX/GDP & $32.6 \%$ & $43.1 \%$ & $43.1 \%$ & $35.4 \%$ & $32.4 \%$ & $38.1 \%$ & $35.6 \%$ \\
\hline $\begin{array}{l}\text { Gap to } \\
\text { OECD }\end{array}$ & $-0.9 \%$ & $10.1 \%$ & $10.1 \%$ & $1.9 \%$ & $-1.1 \%$ & $4.6 \%$ & $2.1 \%$ \\
\hline Country & IRL & ISR & ITA & JAP & KOR & LAT & LUX \\
\hline TAX/GDP & $28.8 \%$ & $32.8 \%$ & $41.3 \%$ & $27.8 \%$ & $22.7 \%$ & $28.6 \%$ & $37.4 \%$ \\
\hline $\begin{array}{l}\text { Gap to } \\
\text { OECD }\end{array}$ & $-4.7 \%$ & $-0.7 \%$ & $7.8 \%$ & $-5.7 \%$ & $-10.8 \%$ & $-4.9 \%$ & $3.9 \%$ \\
\hline Country & MEX & NET & NZ & NOR & POL & POR & SLK \\
\hline TAX/GDP & $13.7 \%$ & $36.4 \%$ & $32.7 \%$ & $41.3 \%$ & $33.2 \%$ & $31.4 \%$ & $31.8 \%$ \\
\hline $\begin{array}{l}\text { Gap to } \\
\text { OECD }\end{array}$ & $-19.8 \%$ & $2.9 \%$ & $-0.8 \%$ & $7.8 \%$ & $-0.3 \%$ & $-2.1 \%$ & $-1.7 \%$ \\
\hline Country & SLO & SPA & SWE & SWI & TUR & UK & US \\
\hline TAX/GDP & $36.9 \%$ & $33.1 \%$ & $45.4 \%$ & $26.7 \%$ & $25.0 \%$ & $32.2 \%$ & $25.8 \%$ \\
\hline $\begin{array}{l}\text { Gap to } \\
\text { OECD }\end{array}$ & $3.4 \%$ & $-0.4 \%$ & $11.9 \%$ & $-6.8 \%$ & $-8.5 \%$ & $-1.3 \%$ & $-7.7 \%$ \\
\hline
\end{tabular}


Jelena Andrašić, Branimir Kalaš, Vera Mirović, Nada Milenković, Miloš Pjanić

The next table shows ratio TAX/GDP in observed countries where this ratio is reflected as tax revenue as a percentage of the gross domestic product. How we get a precise review of tax level in these countries, table manifests country level and comparison to OECD of 33.5\%. Looking by country, more than half countries have beyond average TAX/GDP were especially Belgium, Denmark, Finland, France and Sweden stand out compared to other countries.

For example, Denmark and Sweden have TAX/GDP ratio of $46.3 \%$ and $45.4 \%$ which is much more than average of OECD countries. Likewise, countries as Austria, Italy, Norway, Hungary and Luxembourg have TAX/GDP ratio above OECD average ratio, but it is on a level between 38\%-42\%. On the other hand, there are many countries with a similar trend of OECD average ratio as Germany, Iceland, Netherland and Slovenia. However, TAX/GDP ratio is less than average OECD ratio in Australia, Canada, Chile, Czech, Estonia, Greece, Ireland, Israel, Japan, Korea, Latvia, Mexico, New Zealand, Poland, Portugal, Slovakia, Spain, Switzerland, Turkey, United Kingdom and the United States. Mexico, Chile and Korea are countries that have the smallest TAX/GDP ratio of $13.7 \%, 19.9 \%$ and $22.7 \%$ compared to other OECD countries. Also, Switzerland, Turkey and United States have similar TAX/GDP ratios at the level of $25-26 \%$.

\section{Empirical results}

Considering that study examines thirty-five countries in twenty-one period, authors used panel regression model and diagnostics tests for appropriate selection model. First, it is presented a descriptive statistics of explanatory variables.

Table 4. Descriptive statistics

\begin{tabular}{l|c|c|c|c|c}
\hline Variable & Mean & Std. Dev. & Min & Max & Obs. \\
\hline GDP & 2.535883 & 3.066207 & -14.72 & 11.9 & 735 \\
\hline INF & 3.638219 & 7.266857 & -1.69 & 85.65 & 735 \\
\hline UNM & 7.737306 & 4.020423 & 1.7 & 27.47 & 735 \\
\hline GE & 41.62015 & 8.955339 & 14.66 & 65.29 & 735 \\
\hline INV & 23.45154 & 4.200107 & 9.83 & 41.54 & 735 \\
\hline TRgrowth & 6.633769 & 9.695418 & -22.2 & 114.4 & 735 \\
\hline PIT & 7.768027 & 4.911325 & 0 & 26.8 & 735 \\
\hline CIT & 2.995918 & 1.519146 & 0.6 & 12.6 & 735 \\
\hline SOC & 8.753878 & 4.730728 & 0 & 18 & 735 \\
\hline TOG & 10.77384 & 2.75453 & 4.2 & 17.2 & 735 \\
\hline TOP & 1.778776 & 1.040821 & 0.2 & 7.3 & 735 \\
\hline
\end{tabular}

Based on results of 735 observations, it can see tax revenue growth, government expenditure and inflation have a highest standard deviation, which is much more than other variables. This can be explained by the fact there is a wide range between the lowest and highest tax revenue growth, government expenditure 
Econometric Modelling of Tax Impact on Economic Growth: Panel Evidence from OECD Countries

and inflation rate in selected countries. Thus, for example, in 1997, Turkey recorded the highest inflation rate of $85.65 \%$, while on the other hand in the same year, Australia had the inflation rate of $0.22 \%$. Also, a wide range is recorded in tax revenue growth, where this variable was $111.4 \%$ in 1996 in Turkey again, while Latvia had the highest decline in tax revenue in 2009 where they dropped for $22.2 \%$. The high standard deviation of government expenditure is caused by extremely high share of this variable in gross domestic product in Ireland 2010, while the lowest share is recorded in Korea 1997 when it was $14.66 \%$. On the other hand, tax on goods and services and corporate income tax have the smallest standard deviations of 1.040821 and 1.519146 in observed countries.

Table 5. Panel unit root test

\begin{tabular}{|c|c|c|c|c|}
\hline \multicolumn{5}{|c|}{$\mathrm{H}_{0}$ : Panels contain unit roots } \\
\hline \multicolumn{5}{|c|}{$\mathrm{H}_{\mathrm{a}}$ : Panels are stationary } \\
\hline Variables & $\begin{array}{l}\text { Number of } \\
\text { panels }\end{array}$ & $\begin{array}{l}\text { Levin-Lin-Chu } \\
\text { test }\end{array}$ & Breitung test & $\begin{array}{c}\text { Harris-Tzavalis } \\
\text { test }\end{array}$ \\
\hline GDP & 35 & $\begin{array}{c}-10.2999 * * * \\
(0.0000)\end{array}$ & $\begin{array}{c}-10.0412 * * * \\
(0.0000)\end{array}$ & $\begin{array}{c}0.3633 * * * \\
(0.0000)\end{array}$ \\
\hline INF & 35 & $\begin{array}{c}-7.4784 * * * \\
(0.0000)\end{array}$ & $\begin{array}{c}-3.3316^{* * * *} \\
(0.0004)\end{array}$ & $\begin{array}{c}0.7926 * * * \\
(0.0015)\end{array}$ \\
\hline UNM & 35 & $\begin{array}{c}-9.8128 * * * \\
(0.0000) \\
\end{array}$ & $\begin{array}{c}-3.4416^{* *} \\
(0.0003) \\
\end{array}$ & $\begin{array}{c}0.8065^{* * *} * \\
(0.0084) \\
\end{array}$ \\
\hline GE & 35 & $\begin{array}{c}-6.1453 * * * \\
(0.0000)\end{array}$ & $\begin{array}{c}-4.3005 * * \\
(0.0000)\end{array}$ & $\begin{array}{c}0.6587 * * * \\
(0.0000)\end{array}$ \\
\hline INV & 35 & $\begin{array}{c}-7.3182 * * * \\
(0.0000)\end{array}$ & $\begin{array}{c}-4.0206 * * * \\
(0.0000)\end{array}$ & $\begin{array}{c}0.7174 * * * \\
(0.0000)\end{array}$ \\
\hline TRgrowth & 35 & $\begin{array}{c}-10.7752^{* * * *} \\
(0.0000)\end{array}$ & $\begin{array}{c}-6.2250 * * * \\
(0.0000)\end{array}$ & $\begin{array}{c}0.5883 * * * \\
(0.0000)\end{array}$ \\
\hline PIT & 35 & $\begin{array}{c}-5.1969 * * * \\
(0.0000)\end{array}$ & $\begin{array}{c}-3.6548 * * * \\
(0.0001)\end{array}$ & $\begin{array}{c}0.7633 * * * \\
(0.0000)\end{array}$ \\
\hline CIT & 35 & $\begin{array}{c}-7.5359 * * * \\
(0.0000) \\
\end{array}$ & $\begin{array}{c}-5.0528 * * \\
(0.0000) \\
\end{array}$ & $\begin{array}{c}0.6904 * * * \\
(0.0000) \\
\end{array}$ \\
\hline SOC & 35 & $\begin{array}{c}-7.0473 * * * \\
(0.0000)\end{array}$ & $\begin{array}{l}-1.3555^{*} \\
(0.0876)\end{array}$ & $\begin{array}{c}0.7784 * * * \\
(0.0002)\end{array}$ \\
\hline TOG & 35 & $\begin{array}{c}-7.0473 * * * \\
(0.0000)\end{array}$ & $\begin{array}{c}-3.4043 * * * \\
(0.0003)\end{array}$ & $\begin{array}{c}0.7219^{* * * *} \\
(0.0000)\end{array}$ \\
\hline TOP & 35 & $\begin{array}{c}-7.5359 * * * \\
(0.0000)\end{array}$ & $\begin{array}{c}-3.1628 * * * \\
(0.0008)\end{array}$ & $\begin{array}{c}0.3640 * * * \\
(0.000)\end{array}$ \\
\hline
\end{tabular}

in parentheses are p-values. ${ }^{* * *},{ }^{*} *$ and $*$ indicates rejecting the null hypothesis of nonstationary at $1 \%, 5 \%$ and $10 \%$ level, respectively 
Jelena Andrašić, Branimir Kalaš, Vera Mirović, Nada Milenković, Miloš Pjanić

\begin{tabular}{c|c|c}
\hline \multicolumn{3}{c}{ Table 6. Multicollinearity test } \\
\hline Variable & VIF & $1 /$ VIF \\
\hline INF & 3.80 & 0.263032 \\
\hline UNM & 1.40 & 0.712068 \\
\hline GE & 4.74 & 0.211115 \\
\hline INV & 1.43 & 0.701683 \\
\hline Trgrowth & 3.75 & 0.266651 \\
\hline PIT & 2.42 & 0.413863 \\
\hline CIT & 1.18 & 0.848579 \\
\hline SOC & 2.73 & 0.365952 \\
\hline TOG & 1.95 & 0.513371 \\
\hline TOP & 1.51 & 0.660534 \\
\hline Mean VIF & &
\end{tabular}

One of the essential conditions for proper regression model is the potential absence of multicollinearity. To detect potential multicollinearity problem, authors used Variance Inflation Factor test. Based on results from Table 6, it can conclude there is no multicollinearity in the model because VIF test value is 2.49 which is less than reference value 10. After that, study ensures the model is appropriately designed, we can set panel regression models for observed countries that are presented in Table 7.

Table 7. Panel regression models

\begin{tabular}{l|c|c|c|c}
\hline \multirow{2}{*}{ Variable } & \multicolumn{2}{|c|}{ GLS model } & \multicolumn{2}{c}{ FE model } \\
\cline { 2 - 5 } INF & Coef. & Std. Err. & Coef. & Std. Err. \\
\hline UNM & $\begin{array}{c}-.2988273^{* *} \\
(0.000)\end{array}$ & .0214461 & $\begin{array}{c}.2929342^{* *} \\
(0.000)\end{array}$ & .0227234 \\
\hline GE & $\begin{array}{c}-.0579261 \\
(0.057)\end{array}$ & .0304682 & $\begin{array}{c}-.1321866^{* *} \\
(0.001)\end{array}$ & .0412443 \\
\hline INV & $\begin{array}{c}-.1109135^{* *} \\
(0.000)\end{array}$ & .0238033 & $\begin{array}{c}-.18646^{* *} \\
(0.000)\end{array}$ & .0307741 \\
\hline TRgrowth & $\begin{array}{c}.2251524 \\
(0.000)\end{array}$ & .0266006 & $\begin{array}{c}.2935282^{* *} \\
(0.000)\end{array}$ & .0326573 \\
\hline PIT & $\begin{array}{c}.3051553^{* *} \\
(0.000)\end{array}$ & .0152212 & $\begin{array}{c}.2943094 * * \\
(0.000)\end{array}$ & .0154337 \\
\hline CIT & $\begin{array}{c}.0736968^{*} \\
(0.044)\end{array}$ & .0366705 & $\begin{array}{c}.0842556 \\
(0.415)\end{array}$ & .1033309 \\
\hline SOC & $\begin{array}{c}-.0327405 \\
(0.671)\end{array}$ & .0769846 & $\begin{array}{c}-.0764687 \\
(0.489)\end{array}$ & .1105312 \\
\hline TOG & $\begin{array}{c}.0259602 \\
(0.514)\end{array}$ & .0397357 & $\begin{array}{c}-.0950097 \\
(0.460)\end{array}$ & .1284157 \\
\hline
\end{tabular}


Econometric Modelling of Tax Impact on Economic Growth: Panel Evidence from OECD Countries

\begin{tabular}{l|r|r|r|r}
\hline TOP & $\begin{array}{c}.0582015 \\
(0.666)\end{array}$ & .1348605 & $\begin{array}{c}.2121899^{*} \\
(0.048)\end{array}$ & \multicolumn{1}{c}{.2392826} \\
\hline _cons & $\begin{array}{c}-2.360594^{*} \\
(0.037)\end{array}$ & 1.132169 & $\begin{array}{c}.6935183 \\
(0.740)\end{array}$ & 2.088137 \\
\hline Number of group & & 21 & & 31 \\
\hline $\begin{array}{l}\text { Number of } \\
\text { countries }\end{array}$ & 35 & & 0.5573 \\
\hline R-square & & 0.5412 & & 0.0000 \\
\hline Prob F & 0.0000 & & 735 \\
\hline Observation & 735 & & 2 \\
\hline
\end{tabular}

Note: statistical significance $1 \%$ **

Statistical significance 5\%*

Table 7 reflects panel regression models that measure the impact of macroeconomic determinants and taxes on gross domestic product by evaluation of random effect model and fixed effect model. Both models show a negative impact of inflation, unemployment and government expenditure on gross domestic product, while investment has a positive effect on economic growth. The difference is reflected that fixed effect model shows all macroeconomic determinants have statistically significant impact on the gross domestic product. Looking the taxes, models manifest significant and positive impact of tax revenue growth on economic growth. On one side, random effect model reflects the positive impact of personal income tax and the negative impact of corporate income tax, while fixed effect model gives the inverse result. Also, both models ensure the significant impact of tax on goods and services, where p-value is less than 0.05 . Both models are adequate designed, where R-square is more than $50 \%$ while $\mathrm{F}$ test is 0.0000 which enable argument that model is statistically significant. It is necessary to choose one of these models, so analysis includes Hausman test which is represented in Table 8.

Table 8. Hausman test

\begin{tabular}{l|l|l}
\hline & Result & Conclusion \\
\hline $\begin{array}{l}\text { Random effect model vs } \\
\text { fixed effect model }\end{array}$ & $\begin{array}{l}\text { chi2 }(10)=(\mathrm{b}-\mathrm{B})^{\prime}\left[\left(\mathrm{V}_{-} \mathrm{b}-\mathrm{V}_{-} \mathrm{B}\right)^{\wedge}(-1)\right](\mathrm{b}-\mathrm{B}) \\
=53.24\end{array}$ & $\begin{array}{l}\text { Fixed effect model is an } \\
\text { appropriate }\end{array}$ \\
\cline { 2 - 3 } & Prob>chi $=0.0000$ & \\
\hline
\end{tabular}

Model GDP $\mathrm{GD}_{Y}=0.6935183-0.2929342 x_{1}+0.1321866 x_{2}-0.18646 x_{3}+0.2935282 x_{4}+$ $0.2943094 x_{5}+0.0842556 x_{6}-0.0764687 x_{7}-0.0950097 x_{8}-0.6015496 x_{9}+0.2121899 x_{10}$

In order to choose an adequate model, Hausman test is included in the analysis, where result shows that fixed effect model is appropriate ( $p$-value $=0.0000)$. If we concentrate on taxes and their impact, the model manifests the positive impact of 
Jelena Andrašić, Branimir Kalaš, Vera Mirović, Nada Milenković, Miloš Pjanić

tax revenue growth, personal income tax and tax on property on gross domestic product in selected OECD countries. On the other hand, corporate income tax, social security contributions, tax on goods and services have a negative effect on gross domestic product in these countries. Looking their p-values, there is a statistically significant impact of tax revenue growth, tax on goods and services and tax on property, while personal income tax and corporate income tax do not have a significant impact on economic growth measured by gross domestic product. Results show that $1 \%$ increase of tax revenue growth enhances the gross domestic product for $0.29 \%$ which is confirmed previous studies that manifested significant and positive relationship between these variables. Further, there is recorded the significant and positive effect of tax on property on economic growth, where $1 \%$ increase of this tax form raises a gross domestic product for $0.21 \%$. On the contrary, tax on goods and services have a harmful effect on economic growth, where $1 \%$ increase of them cause gross domestic product drop of $0.60 \%$, which is statistically significant because p-value is less than 0.05 .

\section{Conclusion}

We have researched the impact of taxes on economic growth in 35 OECD countries from 1996 to 2016. Empirical analysis has included panel fixed effect model which has estimated the effect of tax revenue growth, personal income tax, corporate income tax, social security contributions, tax on goods and services and tax on property on key macroeconomic determinants as a gross domestic product which is a proxy for economic growth. Bearing in mind that taxes is not the only factor for economic growth, analysis has included inflation, unemployment, government expenditure and investment. Based on results, all macroeconomic determinants have statistically significant effect on gross domestic product, while on the other hand, taxes such a tax on goods and services, tax on property and tax revenue growth have statistically significant impact on the gross domestic product. Other tax forms such as personal income tax has positive effect on economic growth and corporate income tax and social security contributions have negative impact, but their common characteristics is no statistically significant impact on economic growth. Looking the taxes which impact is significant for the economy in OECD countries, it can notice that $1 \%$ increase of tax revenue growth raises a gross domestic product for $0.29 \%$ which is confirmed previous studies that reflected the significant and positive relationship between these variables. Similarly, $1 \%$ increase of tax on property enhances the gross domestic product for $0.21 \%$, while tax on goods and services have a negative impact on economic growth, where $1 \%$ increase of them cause gross domestic product drop of $0.60 \%$.

The contribution of the paper is reflected in the fact that we have ensured the quantitive measurement of tax forms and analysis has enabled informatical support for policy makers about which taxes are essential for economic growth and how 
Econometric Modelling of Tax Impact on Economic Growth: Panel Evidence from OECD Countries

they affect the economy in OECD countries. Looking the different impact of taxes, it is necessary to increase a share of personal income tax and tax on property and simultaneously reduce percentage share of tax on goods and services because of harmful effect on economic growth. The paper has provided a better understanding of the relation between tax forms and economic growth as well as the character of their influence. Results have given a certain guidance to economic policy makers in determining tax policy in selected countries, where profiling of tax policy should focus on creating the appropriate tax structure and thus enable the improvement and acceleration of economic growth in OECD countries.

\section{REFERENCES}

[1] Alinaghi, N. (2015), Taxes and Economic Growth in OECD Countries: A Meta-Regression Analysis. NZAE conference, Wellington, New Zealand;

[2] Arnold, J. (2008), Do Tax Structures Affect Aggregate Economic Growth?:

Empirical Evidence from a Panel of OECD Countries. OECD Economics Department Working Papers, No. 643, OECD Publishing, Paris.

http://dx.doi.org/10.1787/236001777843;

[3] Asteriou, D. \& Stephen, H. (2007), Applied Econometrics; Third Edition, Palgrave Macmillan;

[4]Bania, N., Gray, J. \& Stone, J. (2007), Growth, Taxes and Government Expenditures: Growth Hills for U.S. States. National Tax Journal, 60, 193-204;

[5]Barro, R, J. (1990), Government Spending in a Simple Model of

Endogeneous Growth. Journal of Political Economy, 98(5), 103-125;

[6]Barro, R. \& Redlick, C. (2011), Macroeconomic Effects of Government

Purchases and Taxes. Quarterly Journal of Economics, 126, 51-102;

[7]Daveri, F. \& Tabellini, G. (2000), Unemployment, Growth and Taxation in Industrial Countries. Economic policy, 15(30), 47-104;

[8]Engen, E. \& Skinner, J. (1996), Taxation and Economic Growth. National Tax Journal, 49(4), 617-642;

[9]Ferede, E. \& Dahlby, B. (2012), The Impact of Tax Cuts on Economic Growth: Evidence from the Canadian Provinces. National Tax Journal, 65(3), 563-594;

[10]Gale, W., Krupkin, A. \& Rueben, K. (2015), The Relationship between

Taxes and Growth: New Evidence. National Tax Journal, 68(4), 919-942;

[11]Gemmell, N., Kneller, R. \& Sanz, I. (2011), The Timing and Persistence of

Fiscal Policy Impacts on Growth: Evidence from OECD Countries. Economic Journal, 121, 33-58;

[12]Helms, L. J. (1985), The Effect of State and Local Taxes on Economic Growth: A Time Series Cross-Section Approach. Review of Economics and Statistics, 67(4), 574-582; 
Jelena Andrašić, Branimir Kalaš, Vera Mirović, Nada Milenković, Miloš Pjanić

[13]Johansson, A., Heady, C., Arnold, J., Brys, B. \& Vartia, L. (2008), Tax and Economic Growth. OECD Economic Department, Working Paper No. 620. https://www.oecd.org/tax/tax-policy/41000592.pdf;

[14]Kneller, R., Bleaney, M.F. \& Gemmell, N. (1999), Fiscal Policy and Growth: Evidence from OECD Countries. Journal of Public Economics, 74(2), 171-190;

[15]Lee, Y. \& Gordon, R. (2005), Tax Structure and Economic Growth. Journal of Public Economics, 89(5), 1027-1043;

[16]Li, J.F. \& Lin, Z.X. (2015), The Impact of Sales Tax on Economic Growth in the United States: An ARDL Bounds Testing Approach. Applied Economics Letters, 22(15), 1-5, DOI: 10.1080/13504841.2015.1023933;

[17]Mankiw, G., Weinzierl, M. \& Yagan, D. (2009), Optimal Taxation in Theory and Practice. Journal of Economic Perspectives, 23(4), 147-174, DOI: 10.1257/jep.23.4.147;

[18]Mendoza, E.G., Milesi-Ferretti, G.M. \& Asea, P. (1997), On the Ineffectiveness of Tax Policy in Altering Long-Run Growth: Harberger's Superneultrality Conjecture. Journal of Public Economics, 66(1), 99-126; [19]Mertens, K. \& Ravn, M. (2013), The Dynamic Effects of Personal and Corporate Income Tax Changes in the United States. American Economic Review, 103(4): 1212-1247;

[20]Myles, G. (2000), Taxation and Economic Growth. Fiscal Studies, 21(1), 141-168, DOI: 10.1111/j.1475-5890.2000.tb00583.x;

[21]Pjesky, R. J. (2006), What Do We Know about Taxes and State Economic Development? A Replication and Extension of Five Key Studies. The Journal of Economics, 32(1), 25-40;

[22]Reed, R. (2008), The Robust Relationship between Taxes and U.S. State Income Growth. National Tax Journal, 61, 57-80;

[23]Romer, C. \& Romer, D. (2010), The Macroeconomic Effects of Tax

Changes: Estimated Based on a New Measure of Fiscal Schocks. American

Economic Review, 100(3), 763-801, DOI: 10.3386/w13264;

[24]Solow, R.M. (1956), A Contribution to the Theory of Economic Growth. The Quarterly Journal of Economics, 70(1), 65-94, DOI:

https://doi.org/10.2307/188513;

[25]Tosun, M.S. \& Abizadeh, S. (2005), Economic Growth and Tax

Components: An analysis of Tax changes in OECD. Applied Economics, 37, 2251-2263. 